\title{
Heat Management System in A Vehicle When Parked
}

\author{
Abhirami S, Anand A S, Ashique Lal S, Devapriya S \\ Harisankar U S \\ Asst. Professor, \\ Mechanical Engineering Department, \\ Prof: M D Sreekumar, \\ Head of Mechanical Engineering Department
}

Department of Mechanical Engineering, Rajadhani Institute of Engineering and Technology, Attingal 695101, India

\begin{abstract}
This study aims to formulate competencies in automobile air conditioning system, using TEC for its effectiveness, efficiency, environment friendliness, comfort and convenience. The heating up of the vehicle cabin on being parked under direct sunlight due to green house effect causes immense discomfort to the passengers when they enter the cabin. The proposed design analyses the heating methodology of a passenger car parked under sunlight by experimental methods taking into consideration, the solar irradiance, temperature at various data points in the cabin, on the basis of which, design an air conditioning system by the usage of thermo-electric device and optimizing it to perform more efficiently with the least power consumption suited for imminent technologies in automotive industry.
\end{abstract}

Keywords: TEM (Thermo Electric Module), TEC(Thermo Electric cooling), Cooling Chamber, HVAC (Heating , Ventilation and Air Conditioning) and fins

\section{INTRODUCTION}

The overall idea of the system is to use the roof of a car equipped with solar cells to collect the energy of sunlight in the hot summer. It is stored in the car battery to drive the automobile blower and the TEC. The blower to ventilate the cabin, and the TEC cools the blower duct's air, the air conditioning condensate collected during the driving process is used to cool the hot end of the TEC to improve the cooling effect.

The TEC is a refrigerating device based on the Peltier effect, which has the advantages of small volume and no noise, but the cooling effect is limited because the TEC's refrigeration power is affected by the hot end temperature. The higher the hot end temperature, the lower the cooling power when the input power is constant. Here we are using 4 modules of Peltier device in which we are using 2 heat sinks, one for cold side and other is hot end side.

The design should achieve the primary goal of maintaining ambient temperature in the cabin and also maintain minimum space requirements. The secondary goal is to maintain the interior parts and to protect the goods and products kept at the cabin from aging and damage respectively. Other than the damaging or aging taking place, the other major problem is that the dangerous gases like Benzene, Volatile Organic Chemicals., etc, being released which causes increase in the risk of heart diseases, asthma, emphysema, causes skin cancer, lung cancer and damages to nervous system.

In this study we focus on developing a model that works on non renewable source of energy to maintain ambient atmospheric conditions inside the cabin and by minimal cost. Where the conventional HVAC system consumes about 8 h.p with a unit capacity of 3 tones of engine power, the use of peltier embedded system can overcome this engine power loss making it more efficient.

\section{METHODOLOGY}

The main objective of this project is to design a cooling system installed on a conventional blower of car AC. The idea of cooling is based on Peltier effect, as when a dc current flows through TE modules it generates a heat transfer and temperature difference across the ceramic substrates causing one side of the module to be cold and the other side to be hot. The purpose of the project is to make use of the cold side to cool the ambient air to a lower temperature, so that it can be used as a personal cooler. Testing and measurements are also performed on car ( Hyundai i20 ). A simple temperature controller to interface with the cooling system has also been incorporated. Based on an analysis of sizing and design of the TEC air cooling for car, it can be deduced that the cooling system is indeed feasible. Readings taken during testing also testify to the fact that the TE cooling for car can lower the ambient temperature by 7 degree Celsius.

\section{EXPERIMENTAL SET UP AND SURVEY}

The temperature range inside the cabin due to radiations incident on glass and heating up of cabin space are recorded for over a period of five months from January to May 2020 where temperature survey is conducted. 

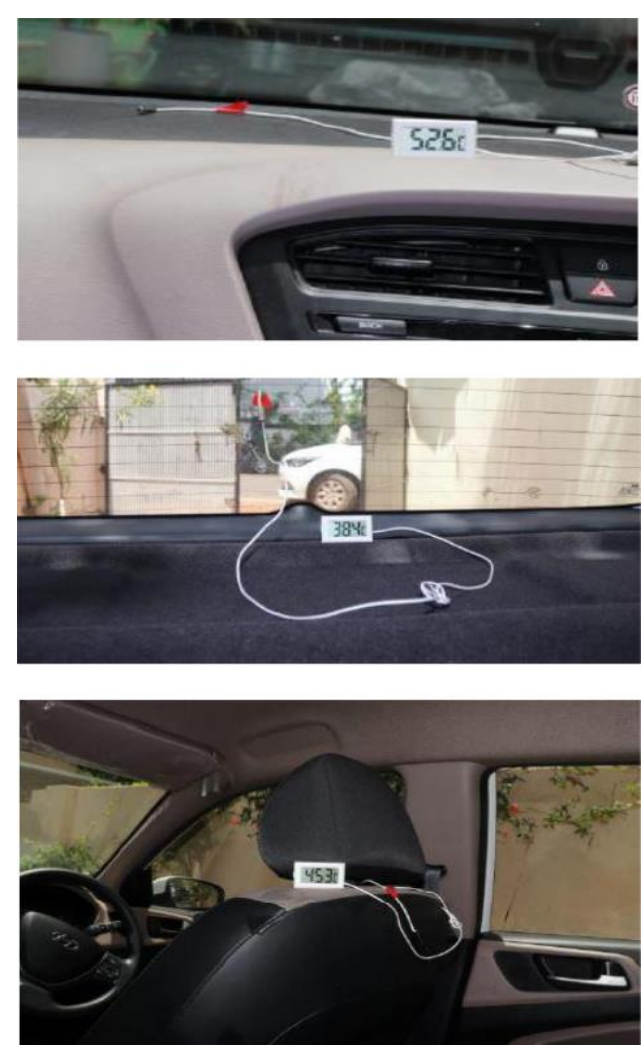

Fig : 3.1 Temperature measurement on dashboard, rear windshield and cabin space
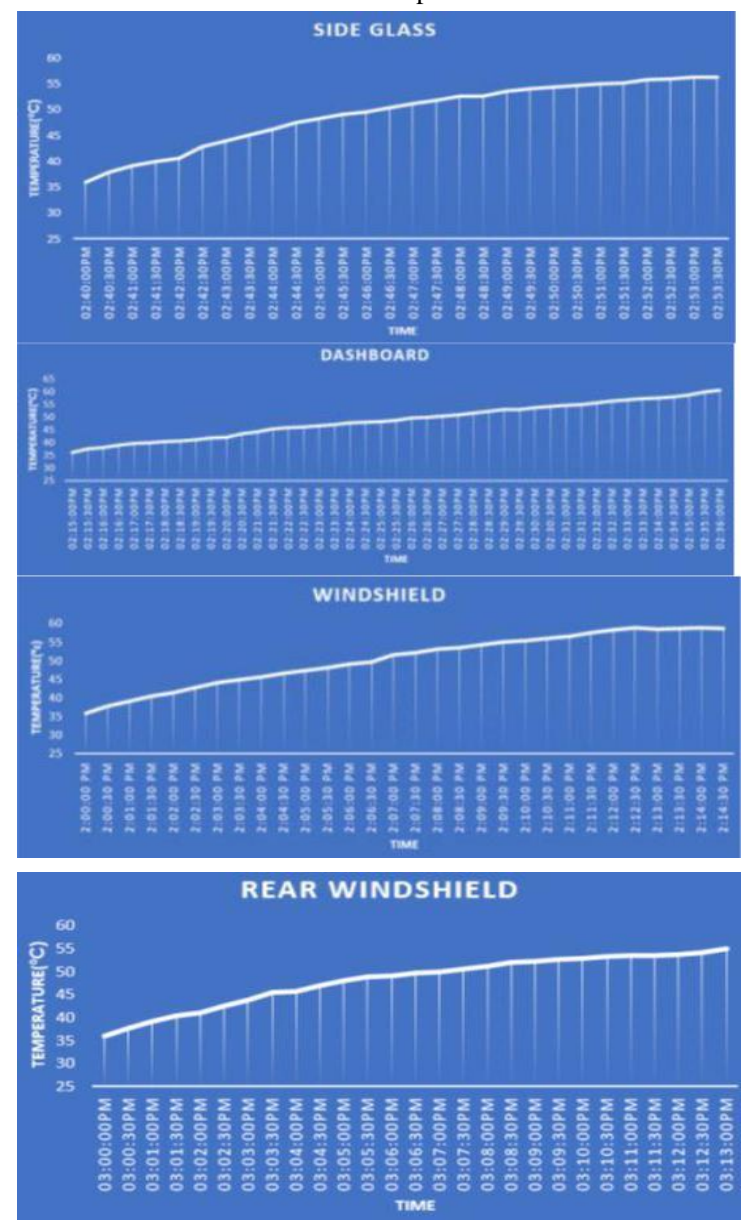

Fig3.2 Temperature Survey of Side Glass, Dashboard, Windshield and Rear Windshield

\section{DESIGN AND CALCULATIONS}

4. IVOLUME OF CAR CABIN

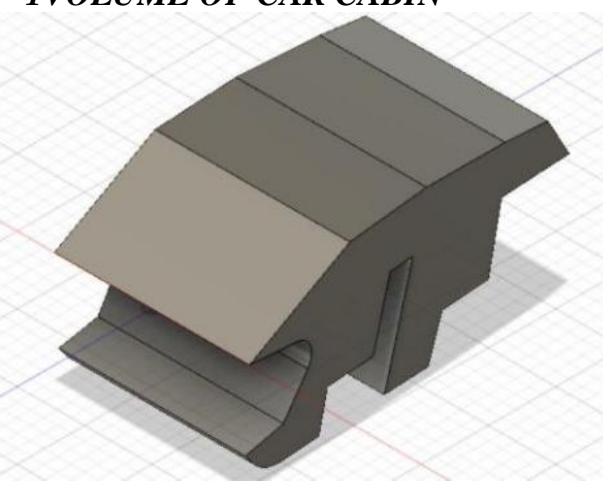

Fig 4.1 Volume of Car cabin

Volume of car cabin $=2300$ Litre

\subsection{HEAT LOAD CALCULATION}

\subsubsection{WINDSHIELD}

The heat generated is $\mathrm{Q}_{1}=\mathrm{A}_{\omega} \mathrm{Z}_{\mathrm{d}} \mathrm{I}_{\mathrm{d}}+\mathrm{A}_{\omega} \mathrm{Z}_{\mathrm{d}} \mathrm{I}_{\mathrm{dif}}$ $=0.9942 \times 0.79 \times(100.29+80.54)$

$$
\mathrm{Q} 1=142.027 \text { Watts }
$$

\subsubsection{SIDE GLASS}

The heat generated is $\mathrm{Q}_{2}=\mathrm{A}_{\omega} \mathrm{Z}_{\mathrm{d}} \mathrm{I}_{\mathrm{d}}+\mathrm{A}_{\omega} \mathrm{Z}_{\mathrm{d}} \mathrm{I}_{\text {dif }}$ $=1.14895 \times 0.79(393.088+104.839)$ $\mathrm{Q} 2=467.762$ Watts

\subsubsection{REAR WINDSHIELD}

The heat generated is $\mathrm{Q}_{3}=\mathrm{A}_{\omega} \mathrm{Z}_{\mathrm{d}} \mathrm{I}_{\mathrm{d}}+\mathrm{A}_{\omega} \mathrm{Z}_{\mathrm{d}} \mathrm{I}_{\text {dif }}$ $=0.3346 \times 0.79 \times(237.063+92.85)$

$$
\text { Q3 }=87.207 \text { Watts }
$$

Total Heat Generated, QT $=$ Q1 + Q2 + Q3

$$
=142.027+467.762+87.207
$$

$$
\text { QT }=696.996 \mathrm{~W}
$$

Therefore, the total maximum heat generated in the cabin space is $700 \mathrm{~W}$. 


\subsection{SELECTION OF PELTIER}

Heat Transmitted $=30 \mathrm{~W}$

Hot Side Temperature $=50^{\circ} \mathrm{C}$

Cold Temperature $\quad=8^{\circ} \mathrm{C}$

Voltage $=12 \mathrm{~V}$

Current $=6.2 \mathrm{~A}$

Power $=74.4 \mathrm{~W}$

Therefore based on the study and analysis we selected the

Peltier module of

Peltier $=\mathrm{CP} 85438$

\subsection{COOLING LOAD CALCULATION}

\subsubsection{ADIABATIC MIXING}

Temperature of air at cabin, $\mathrm{Th}=33^{\circ} \mathrm{C}$

$$
=306 \mathrm{~K}
$$

Temperature of air from cooling chamber, $\mathrm{Tc}=20^{\circ} \mathrm{C}$ $=293 \mathrm{~K}$

Mass of air at $2300 \mathrm{~L}$ volume,

$\mathrm{mh}=$ Density $\mathrm{x}$ volume

$$
=2.67 \mathrm{~kg}
$$

Equation of Adiabatic Mixing,

$$
m_{h} C_{p}\left(T_{h}-T_{f}\right)=m_{c} C_{p}\left(T_{f}-T_{c}\right)
$$

Here we are finding the mass of cooling air, $\mathrm{m}_{\mathrm{c}}=h\left(h^{-}\right) h^{-}$

$$
=2.67 \text { (306-305.9)305.9-293 }
$$

$\mathrm{m}_{\mathrm{c}}=0.020697 \mathrm{~kg}$

\subsubsection{DESIGN OF COOLING CYLINDER}



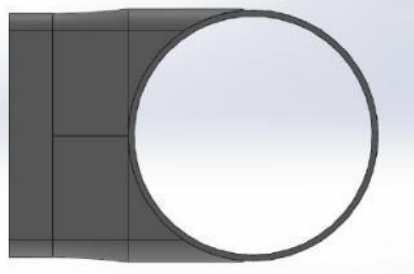

Fig 4.2 Cooling chamber

Volume of Cylinder $=-{ }^{2} \times$

$$
\mathrm{d}_{\mathrm{c}}=0.2 \mathrm{~m}
$$

Effective Chamber volume $\quad=-2 X$

$$
\begin{aligned}
& =-\times 0.22 \times 0.22 \\
& =6.283185 \times 10^{-3} \mathrm{~m}^{3}
\end{aligned}
$$

\subsubsection{DESIGN OF FAN AND CALCULATION OF} EXIT VELOCITY

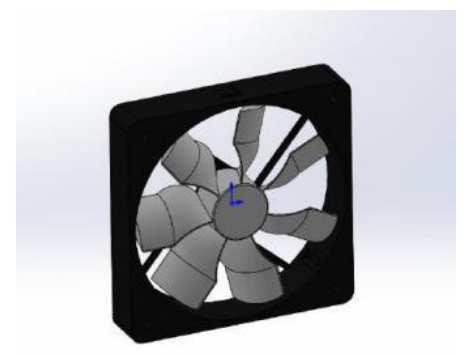

Fig 4.3 Fan

Fan diameter, $\mathrm{d}_{\mathrm{fan}}=18 \mathrm{~cm}=0.18$

$\mathrm{m}$ Required volume flow rate $\overline{=}$

Exit velocity $=$

$$
=0.6749714111 \mathrm{~m} / \mathrm{s}
$$

\subsubsection{DESIGN OF INLET}

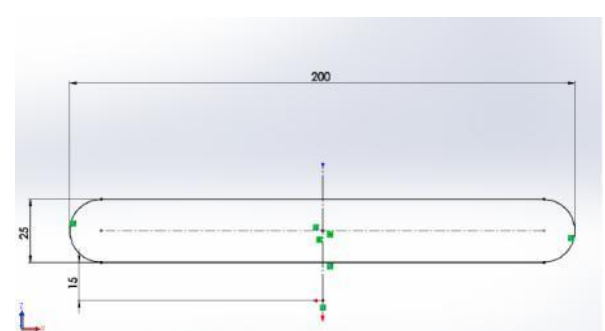

Fig 4.4 Inlet cross section

$\mathrm{D}=0.025 \mathrm{~m}$

$\mathrm{L}=0.175 \mathrm{~m}$ 
Equivalent diameter of circle for inlet slot, $\mathrm{Deq}=$

$$
=78.710 \mathrm{~mm}
$$

Velocity of air at inlet, $\mathrm{U}_{\mathrm{i}}=3.6862508 \mathrm{~m} / \mathrm{s}$

\subsection{CONVECTIVE HEAT TRANSFER CO- EFFICIENT OF AIR ( h)}

\subsubsection{CALCULATING THE REYNOLDS NUMBER OF AIR AT INLET}

$$
\begin{aligned}
\mathrm{R}_{\mathrm{e}} & = \\
& =17811.1455
\end{aligned}
$$

Re $>2300$ turbulent

As the air entering the chamber is turbulent

\subsubsection{CALCULATING THE REYNOLDS NUMBER OF AIR AT FIN}

$\operatorname{Re}=-$

Laminar $=36375.0819 \mathrm{Re}>5 \times 10^{5}$

As the air at the fin surface is laminar flow

Pr at $21.5=0.7027$

To find $h$

$$
\begin{aligned}
N_{u x} & =0.332 \operatorname{Re}^{0.5} \times \operatorname{Pr}^{0.333} \\
& =0.332 \times 36375.0819^{0.5} \times 0.7027^{0.333} \\
& =56.30078
\end{aligned}
$$

Nusselt number, $\mathrm{Nu}=$

$$
\mathrm{h}=9.77869 \mathrm{~W} / \mathrm{m}^{2} \mathrm{~K}
$$

\subsection{DESIGN OF COLD FIN}

\subsubsection{CONVECTION OF FIN}



Fig 4.5 Design of cold fin

Qcv = $(\mathrm{T} b-\mathrm{T}) \tan \mathrm{h}(\mathrm{mL})$

$h=9.77869 \mathrm{~W} / \mathrm{m}^{2} \mathrm{~K}$
$\mathrm{P}=2\left(1 \times 10^{-3}+15 \times 10^{-3}\right)=0.032 \mathrm{~m}$

$\mathrm{A}=1 \times 10^{-3}+15 \times 10^{-3}=1.5 \times 10^{-5} \mathrm{~m}^{2}$

$\mathrm{k}=200 \mathrm{~W} / \mathrm{m} \mathrm{K}$ for aluminium

$\mathrm{T} b=10^{\circ} \mathrm{C}$

$\mathrm{T}=33^{\circ} \mathrm{C}$

$\mathrm{Q}_{\mathrm{cv}}=0.6418108226$

$\mathrm{Qd}_{\mathrm{d}}=16.8025 \mathrm{~W}$

No: of fin $(\mathrm{n})=$

$$
=\approx 27
$$

\subsubsection{CONDUCTION OF FIN}

$\mathrm{Q}_{\mathrm{cd}}=\mathrm{k} \mathrm{A}-$

$$
=0.27074 \mathrm{~J} / \mathrm{s}
$$

Total heat transferred through 'n' Fin,

$\mathrm{QTF}=\mathrm{Qfin} \times \mathrm{n}$

$$
=7.30998 \mathrm{~W} \text { or } \mathrm{J} / \mathrm{s}
$$

Total Peltier Power $=$ Qpelt $=$ QTF $+Q_{d}$

$$
=24.11248 \mathrm{~W} \text { or } \mathrm{J} / \mathrm{s}
$$

4.7

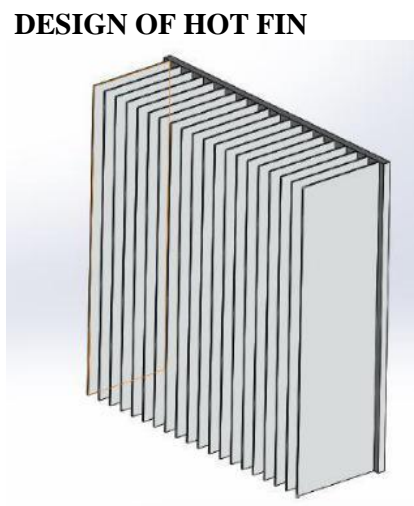

Fig4.6 Design of hot fin

Heat transfer of 1 fin,

$$
\begin{aligned}
\mathrm{Q} & =\sqrt{ } \quad(\mathrm{Tb}-\mathrm{T} \infty) \tan \mathrm{h}(\mathrm{m} 1) \\
& =4.2814 \mathrm{~W}
\end{aligned}
$$

Efficiency of the fin with accessories

$$
\begin{aligned}
& = \\
& =76 \%
\end{aligned}
$$




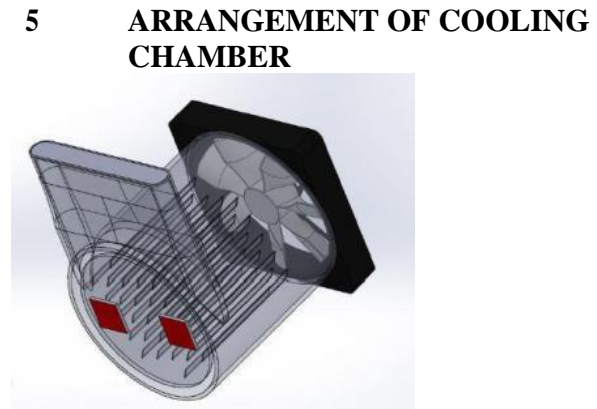

Fig 5.3 Peltier position in cooling chamber

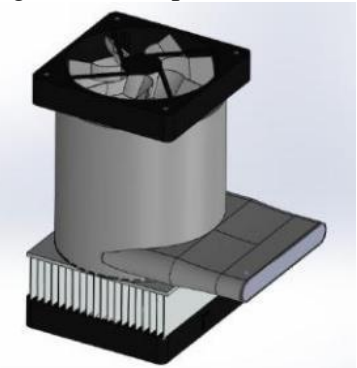

Fig 5.1 Orthogonal view of the cooling chamber

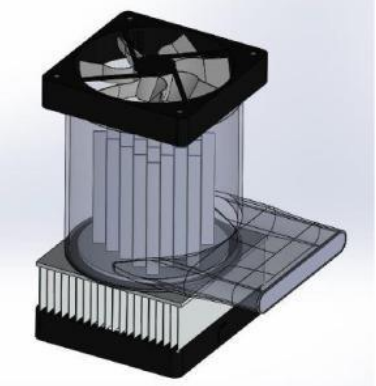

Fig 5.2 Cold fin position in cooling chamber

\section{THERMAL ANALYSIS OF HEAT ABSORPTION FIN \\ 6.4 MATERIAL PROPERTIES}

Model type:

Default failure criterion:

Thermal conductivity:

Specific heat:

Mass density:

\section{Name:}

1060 Alloy

Linear Elastic Isotropic

Max von Mises Stress

$200 \mathrm{~W} /(\mathrm{m} . \mathrm{K})$

$900 \mathrm{~J} /(\mathrm{kg} . \mathrm{K})$

$2700 \mathrm{~kg} / \mathrm{m}^{3}$

\subsection{TEMPERATURE DISTRIBUTION}



Fig 6.1 Thermal analysis of the heat absorption fin

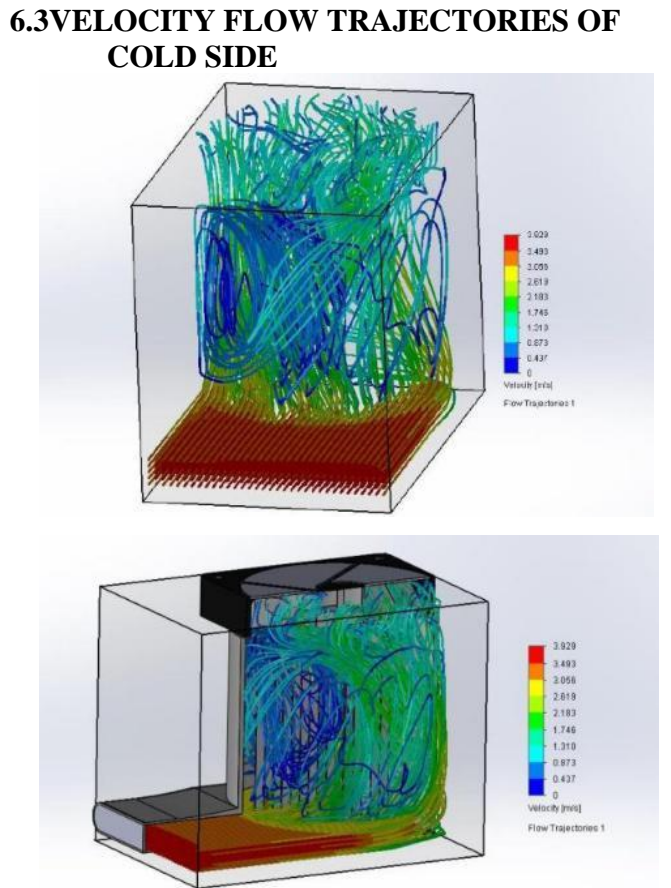

Fig 6.2 Velocity flow of

Trajectories of Cold side

\section{THERMAL ANALYSIS OF HEAT REJECTION FIN}

\subsection{MATERIAL PROPERTIES}

Name:

1060 Alloy

Model type:

Linear Elastic Isotropic

Default failure criterion:

Max von Mises Stress

Thermal conductivity: $200 \mathrm{~W} /(\mathrm{m} . \mathrm{K})$

Specific heat:

$900 \mathrm{~J} /(\mathrm{kg} . \mathrm{K})$

Mass density:

$2700 \mathrm{~m}^{3}$

\subsection{TEMPERATURE DISTRIBUTION}



Fig 7.1 Thermal analysis of the heat rejection fin 


\subsection{VELOCITY TRAJECTORIES}

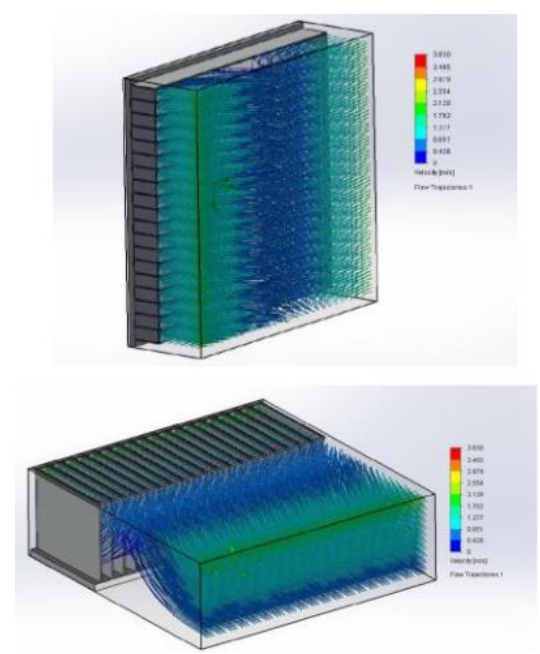

Fig 7.2 Velocity flow of trajectories of Hot side

8. CIRCUIT BLOCK DIAGRAM

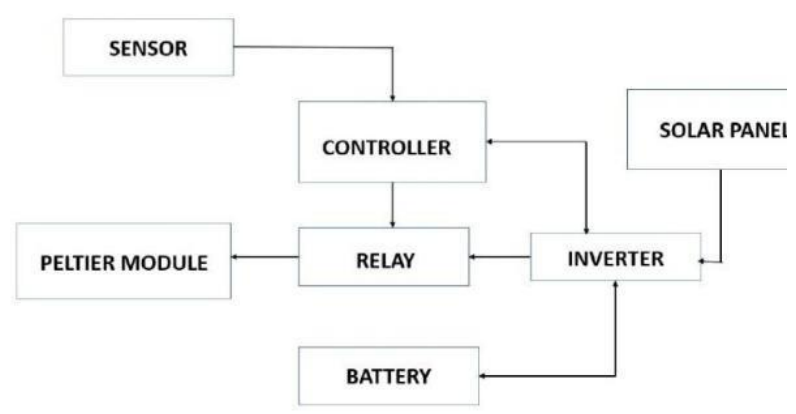

9. RESULTS AND DISCUSSIONS

As per the aim the system will be able to maintain the ambient temperature in the cabin. On the basis of calculations, the proposed design tends to confirm with the expected standards set forward as the base criteria. The system is considered power efficient and reliable for commercial implementation in passenger cars and is assumed to meet the expectations of the consumer base ( as depicted from survey ). The system is designed in such a way that it eases its integration to the existing vehicle designed and implementation in the forth coming vehicles as modified design.

\section{CONCLUSION}

It seems to provide acceptable results conferring to the primary aim to maintain the ambient temperature by implementation of the proposed system into a passenger vehicle.

By the methodology of air recirculation (by suction, cooling and delivery) of cabin air at a specified temperature such that, the rate of cooling tends to match with the rate of solar heating with considerations to compensate for all major thermal loses by taking sufficient design factors. A specific mass flow rate is decided to achieve the same, the air is passed through a chamber with fins to absorb the heat and deliver it back to the cabin using an axial flow fan. Air is hotter near the windshield, by taking into consideration, necessary heat distribution; air is sucked from this portion into the chamber and delivered back into the cabin through dashboard $\mathrm{A} / \mathrm{C}$ vents. The system uses two thermo-electric cooler units working in parallel to achieve the goal. It has an efficiency of 60-65 percent with accessories included. This works on a solar powered control circuit.

\section{ACKNOWLEDGEMENT}

I express my sincere thanks to DR. M.D. SREEKUMAR, Head of Department of Mechanical Engineering, for providing us with an opportunity to undertake this project. We are very much grateful to our Principal Dr. K. C. RAVEENDRANATHAN and Vice Principal Dr. K. BALAN of Rajadhani Institute of Engineering and Technology, Attingal, for supporting us all along. We would like to specially acknowledge our Project Guide MR. HARISANKAR U S, Asst. Professor in Mechanical Engineering and our project coordinator Mr. SREERAJ M.P., Asst. Professor in Mechanical Engineering for their guidance and steering us to the successful completion of this project.

\section{REFERENCES}

[1] PK Nag (2011). Heat and Mass Transfer (Ed. 3), Tata McGraw Hill

[2] RK Rajput (2012). Heat and Mass Transfer (Ed. 5), S Chand Publishing.

[3] CP Kothandaraman, S Subramanyan. (2018) Heat and Mass Transfer Data Book (Ed. 9), New Age.

[4] CP Arora, Refrigeration and Air Conditioning (Ed. 3), Tata McGraw Hill.

[5] RK Rajput (2012) Refrigeration and Air Conditioning (Ed. 2), Katson Books.

[6] ( Paper 1 ) Ma, X., Tan, G., Wang, S., Zhou, D. et al "Passenger Cabin's Parking Cooling System Based on TEC and Air Conditioning Condensate Water," SAE Technical Paper 2019-01-1066, 2019, doi:10.4271/2019-01-1066

[7] ( Paper 2 ) Patil, A., Radle, M., Shome, B., and Ramachandran, S., "One-Dimensional Solar Heat Load Simulation Model for a Parked Car," SAE Technical Paper 2015-01-0356, 2015, doi:10.4271/2015-01-0356.

[8] Peltier Application Note, CUI Inc.

[9] Frederick H. Rohles(Kansas State Univ.), Jr. Stan B. Wallis (The Ford Motor Co.) (1980), Comfort Criteria for AirConditioned Automotive Vehicles, SAE.

[10] ( Paper 3 ) Kaushal Kumar Jha, Viren Bhanot and Venkata Ryali ( Mahindra \& Mahindra) A Simple Model for Calculating Vehicle Thermal Loads." SAE Technical paper 2013-01-0855 Published on 04/08/2013 